Al-Azhar Bull. Sci. Vol. 24, No. 1 (June.): pp. 17-27, 2013.

\title{
EFFECT OF ND-YAG LASER ON DIELECTRIC PROPERTIES OF RABBIT EYE
}

TALAAT. M.S ${ }^{1}$, SAMIRA. M. SALLAM $^{2}$, SOHAIR NEGM ${ }^{3}$, FATMA.METAWE ${ }^{3}$ AND HORIA.F

${ }^{1}$ Department of Physics, , Faculty of Science, Ain Shams University, Egypt

${ }^{2}$ Department of Physics, Faculty of Science, Benha University, Benha, Egypt

${ }^{3}$ Department of Mathematics and Physics, Faculty of engineering, Benha University, , Egypt

\begin{abstract}
This paper is an attempt to investigate the effect of neodymium yag ( Nd:YAG) laser exposure during eye treatment $\left(1064 \mathrm{~nm}, 0.01 \mathrm{w} / \mathrm{cm}^{2}\right.$, spot size $450 \mu \mathrm{m}$, duration time $9 \mathrm{n} \mathrm{sec}$, 30 pulses per sec and time exposure, 0.25 (group A) and $0.1 \mathrm{sec}$ (group B)). We intend to measure the dielectric properties of eye tissues and correlate them with structure. Values of the relative permittivity, dielectric loss and conductivity $\varepsilon, \varepsilon^{\prime \prime} \& \sigma$, are measured for various rabbit ocular tissues (cornea, lens and retina) at the frequency range $100 \mathrm{~Hz}-100 \mathrm{kHz}$ before and after laser exposure. The aim of this work is to test the functional state of the eye tissues exposed to laser beam of the same intensity and duration as that used in lens posterior capsulotomy after cataract surgery, by the use of dielectric method. We tried to adapt the physical conditions surrounding the exposed eye during exposure. The obtained results showed that, for the whole eye, as well as for all eye tissues, both values of permittivity and conductivity showed remarkable decreases than normal values, immediately after laser exposure, for both group A \& B and this reduction begins to diminish with days after exposure approaching normal values approximately after 8 days of exposure. It is evident that, although laser interacts with all cell membrane structures responsible for transport phenomena leading to changes in the dielectric properties, this interaction depends on the tissue type, special function of membrane and magnitude of exposure power and time of exposure which must accurately considered during choosing the laser treatment conditions and the tissue to be treated.
\end{abstract}

\section{Introduction:}

Laser is widely used in all fields of scientific research, medicine, and industry. It is used for a wide variety of surgical operations [1]. However, this is not without possible risks and disadvantages -as with any technology- there may be unanticipated side effects and complications. Laser exposure may affect the eye tissues by inducing biological effects, which mainly depend on the energy absorbed by the eye tissues. The absorbed energy is transmitted to eye tissues and completely transformed into heat [2-4], and the maximum reached temperature and the time during which the tissue submitted to laser lead to different biological effects [5-6]. Because of the high radiant power of many laser systems; a very short exposure time can cause damage [7]. Many factors must be taken into consideration during laser surgery of the eye; wavelength or spectral region of laser radiation, optical density at particular wavelengths, maximum irradiance $\left(\mathrm{W} / \mathrm{cm}^{2}\right)$ or power $(\mathrm{W})$, and also the type of laser system and kind of disease [8-9]. 
$\mathrm{Nd}$ :YAG laser has been frequently used in treatment of eye diseases. It was developed not long after the discovery of the ruby laser in the 1960s. Its high gain, narrow line width, low threshold and physical properties make it a most versatile laser material for a variety of applications spatially in eye treatment [10, 7, 4]. $\mathrm{Nd}$ :YAG laser emits light in the near infrared spectrum at a wavelength of $1064 \mathrm{~nm}$. With this wavelength, Nd:YAG laser energy is less efficiently absorbed by water and more readily absorbed by other materials such as the hemoglobin in red blood cells. The energy penetrates further into the soft tissue (up to $4 \mathrm{~mm}$ ) before being absorbed. Nd:YAG offers a wider application range, in large part because of its unique properties and because it is one of the few lasers that operates efficiently with either flash lamp or diode pump and in pulsed or continuous-wave (CW) mode [11]. Moreover, the delivery system can be a contact or a noncontact system, both of which can influence the tissue insult and the degree of postreatment inflammation.

On applying Nd:YAG laser for eye treatment, it its necessary to consider the possibility and extent of complication [10]. The side effects that have been reported included damage to corneal endothelium, vitreous humor [12], the lens and the retina causing rupture of retinal vessels [13]. The effects may be manifested in biochemical and physiological phenomena in various enzymes, cells, tissues, organs and organisms. These effects may be due to changes in the transport of ions and various molecules across the cell membranes, changes in the characteristic biological activity and dielectric properties of various cells and tissues $[\mathbf{1 4}, \mathbf{8}]$.

Dielectric properties of biological tissues depend mainly on the cellular tissue structure. They are used as a powerful tool for studying molecular and cellular parameters [15-17]. They are considered a good measure of the functional state of the membrane and cytoplasm of the cells (e.g., counter ion relaxation associated with intrinsic membrane changes, dipole reaction in cell membrane, conductivity transport in the extra-cellar medium and through the membrane and tissue water relaxation). Information about tissue structure and composition, e.g. water content or presence of a tumor, might be obtained by measuring the dielectric properties of the tissues. Grant and his colleagues measured the dielectric properties of several ocular tissues, over wide frequency range [18-20], and correlate these properties with tissue structure and function. These properties are obtained from the measurement of complex relative permittivity $\dot{\varepsilon}, \varepsilon^{\prime \prime}$, and conductivity $\sigma$.

Accordingly, in an attempt to investigate the effect of Nd:YAG laser exposure during eye treatment, we intend to measure the dielectric properties of eye tissues and correlate them with structure. Values of the relative permittivity, dielectric loss and conductivity $\varepsilon, \varepsilon^{\prime \prime} \& \sigma$, are measured for various rabbit ocular tissues (cornea, lens and retina) at the frequency range $100 \mathrm{~Hz}-100 \mathrm{KHz}$ before and after laser exposure. The aim of this work is to test the functional state of the eye tissues 
exposed to laser beam of the same intensity and duration as that used in retinal photocoagulation, by the use of dielectric method. We tried to adapt the physical conditions surrounding the exposed eye during exposure.

\section{Materials and methods:}

\section{Animals}

The experiments were performed on total twenty rabbits, weighing $1.5-2 \mathrm{Kg}$ .The rabbits were divided into 4-groups, one unexposed control group and 3 other groups for laser exposure, all housed in separated cages with free access to water and food under 12/12 h light and dark cycle. The rabbits were anesthetized by an intramuscular injection $(0.1 \mathrm{~mL} / \mathrm{Kg}$ body weight $)$ of cocktail made up of ketamine hydrochloride, acepromazine male ate and xylazine. The rabbits were then exposed to Nd-YAG and either immediately scarified, or left for 4 or 8 days in order to study the expected repair mechanisms (recovery periods).

\section{Laser treatments}

Laser irradiation was carried out at nano-technology laboratory, Faculty of engineering in Shobra, Banha University, with pulsed Nd-YAG laser (Model L A B-150 S/N, made in U.S.A) (1064nm, with intensity $0.01 \mathrm{w} / \mathrm{cm}^{2}$., spot size $450 \mu \mathrm{m}$, duration time $9 \mathrm{n}$ sec., 30 pulses per sec and time exposure 0.25 and $0.1 \mathrm{sec}$.).

Each rabbit eye, in each group; right and left eye was exposed, in vivo, to laser with time exposure $0.25 \mathrm{sec} \& 0.1 \mathrm{sec}$ (group (A) and (B) respectively).

\section{Dielectric measurements}

After rabbit decapitation, the eyes were enucleated, moistened with Ringer's solution and placed in the dielectric cell which consists of two parallel silver disc electrodes, $0.5 \mathrm{~cm}$ diameter coated by a non-polarizable silver chloride layer. Measurement of the dielectric parameters of whole eye and ocular tissues (lenscornea-retina), over the frequency range $(100 \mathrm{~Hz}-100 \mathrm{KHz})$ at room temperature, were performed using (BM6304) programmable automatic RLC Bridge. The data of impedance $\mathrm{Z}$, from the bridge, was first corrected for the series impedance measured according to Schwan method, [21]. Using the cell constant, calculated from the dimensions of the sample cell and from the previously measured value of stray capacitance $\mathrm{C}$ in the cell, the sample dielectric properties can be calculated using the equations:

$$
\begin{array}{ll}
\epsilon^{\prime}=\frac{C d}{F_{*} A} & \text { (1) } \quad \mathrm{E}^{\prime \prime}=\mathrm{E}^{\prime} \tan (90-\emptyset) \\
\sigma=\frac{d}{A R} & \text { (3) } \quad Z^{\prime}=Z \cos \emptyset
\end{array}
$$


$Z^{\prime \prime}=Z \sin \emptyset$

$$
\tau=\frac{1}{2 \pi f}\left(\frac{\left(Z_{s-} z^{2}+Z^{n}\right.}{\left(z^{\prime}-Z_{\infty}\right)^{2}+z^{n^{2}}}\right)^{\frac{1}{2(1-h)}}
$$

Where $\mathrm{d}$ is the distance between the two recording electrodes, A: area of tip electrode $=\pi r^{2}$, at $r=0.5 \mathrm{~cm}, \sigma$ : conductivity, $\varepsilon^{\prime}$ : dielectric permittivity, $\varepsilon^{\prime \prime}$ : dielectric loss, $\boldsymbol{\tau}$ : the relaxation time, $\mathbf{f}$ : applied frequency, $\mathbf{h}=\mathbf{2 \alpha}$, where $\boldsymbol{\alpha}$ is the angle between $\mathbf{Z}^{\prime}$ and radius of Cole-Cole semicircle. All these parameters were calculated for each sample; control, immediate and after 4days \& 8days of laser exposure.

\section{Results and Discussion}

The obtained results indicated significant variations in the dielectric parameters of the whole eye and the separated ocular tissues before, immediately, and after 4 \& 8 days of laser exposure for $0.25 \& 0.1$ sec exposure times (group A \& B respectively), at the same conditions similar to that used in eye treatment.

Frequency dependence of relative permittivity and conductivity for whole isolated rabbit eyes and separated cornea, lens and retina are shown in fig $1 \& 2$ while fig 3 shows the Cole - Cole diagrams for these tissues.

The obtained results showed that, for the whole eye, as well as for all eye tissues, both values of permittivity and conductivity showed remarkable decreases than normal values, immediately after laser exposure, for both group A \& B and this reduction begins to diminish with time (not linearly relation because the change not constant with time where the change was rapidly after exposure and this change decreased after days)after exposure approaching normal values approximately after 8 days of exposure.

In these results, the operating wavelength $1064 \mathrm{~nm}$ of Nd-YAG laser transmitted through the ocular tissues with low effect at the cornea. This view is in accord with Crompton [22], who reported that the corneal tissues transmit wavelength between 400 and $1400 \mathrm{~nm}$.

The reduction in permittivity of the whole eye and separated ocular tissues, immediately after laser exposure, may be due to rupture in cell membrane and consequently in ion permeability due to thermal effects of laser. After 8 days of exposure, the permittivity of whole eye and ocular tissues are nearly approached control value. This behavior may be due to the polarization of ions in water contents of tissues and re-polarization of ions beside the cell membrane due to the return to regular permeability of ions through the cell membrane. 
$\operatorname{Group}(\mathbf{A})$
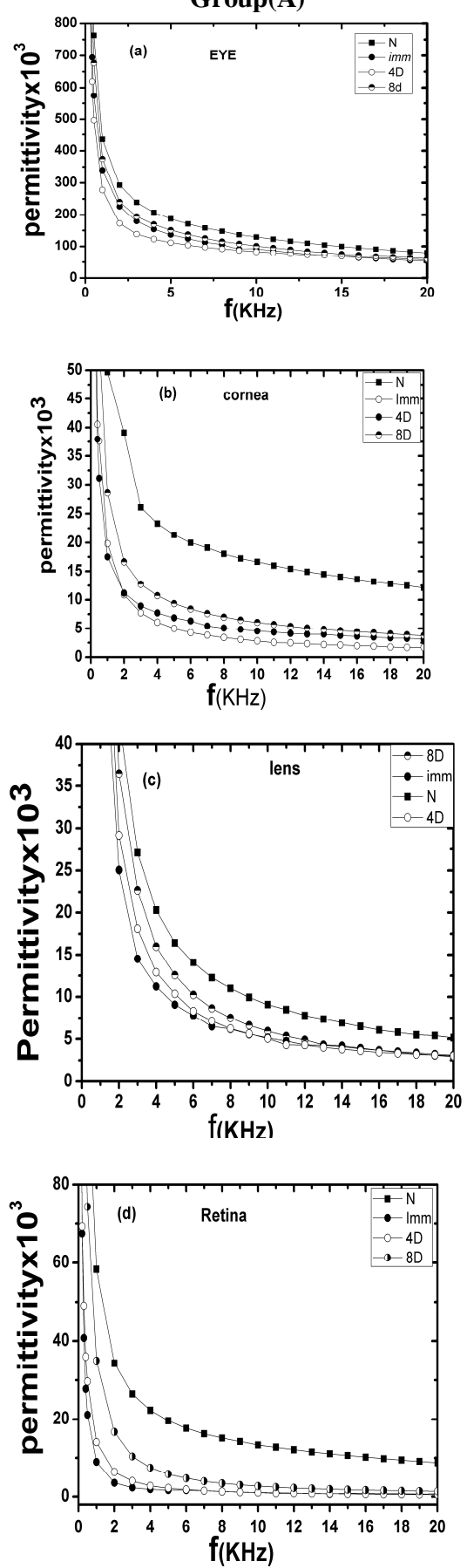

Group(B)
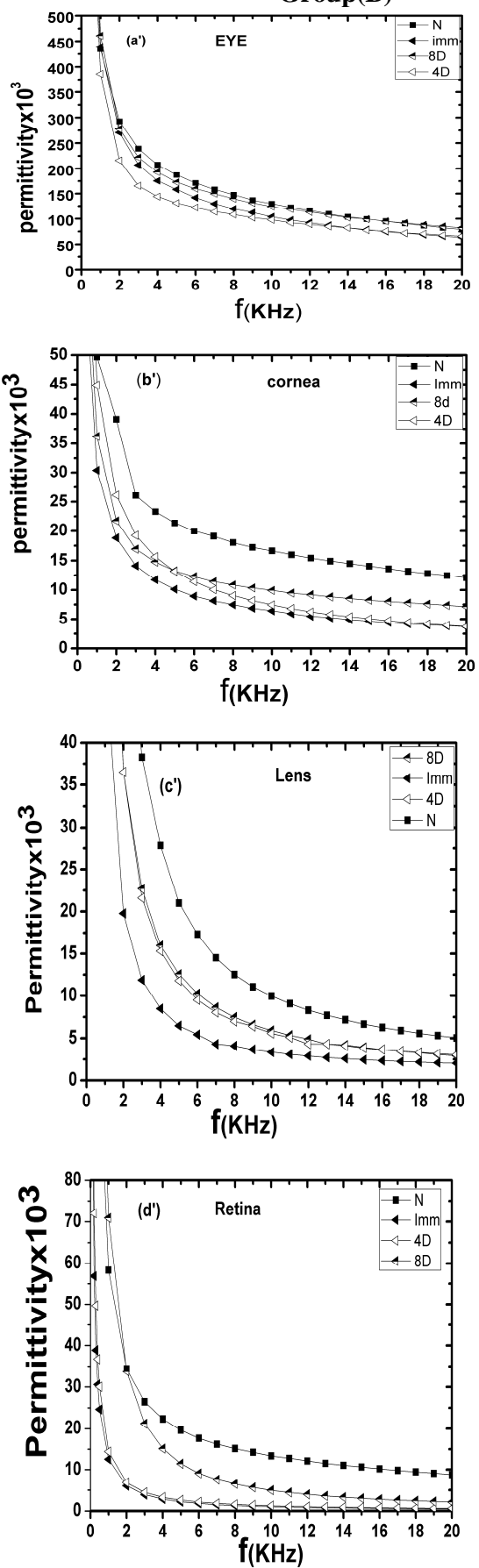

Fig. 1: Frequency dependence of relative permittivity for whole isolated rabbit eyes and separated cornea, lens and retina. 
Group(A): exposure time 0.25sec
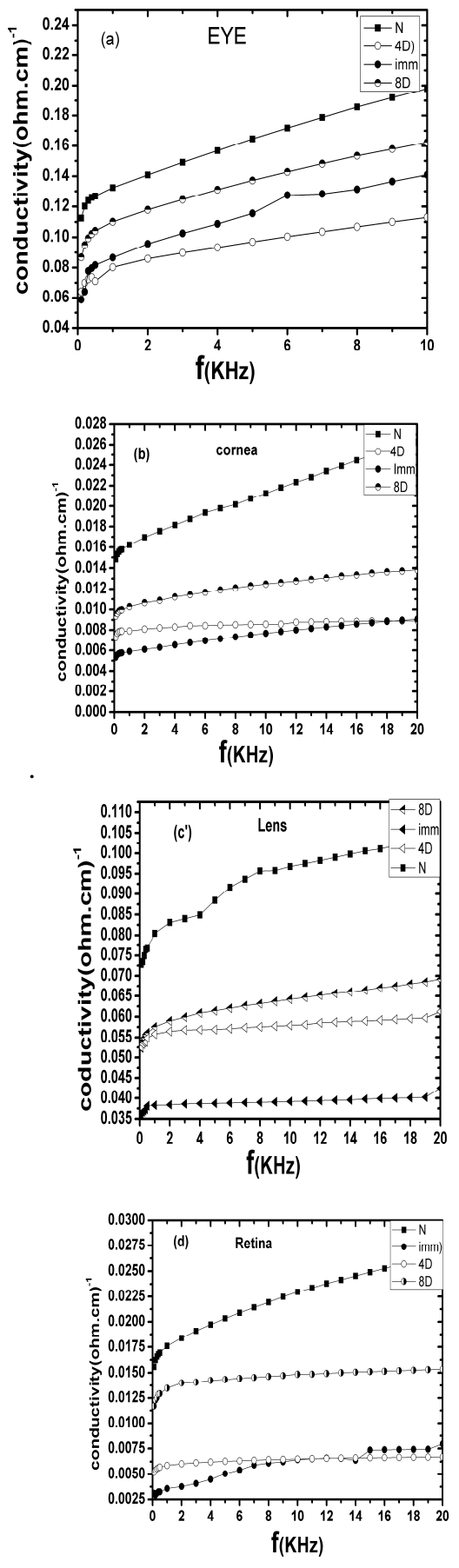

Group(B): exposure time 0. 1sec
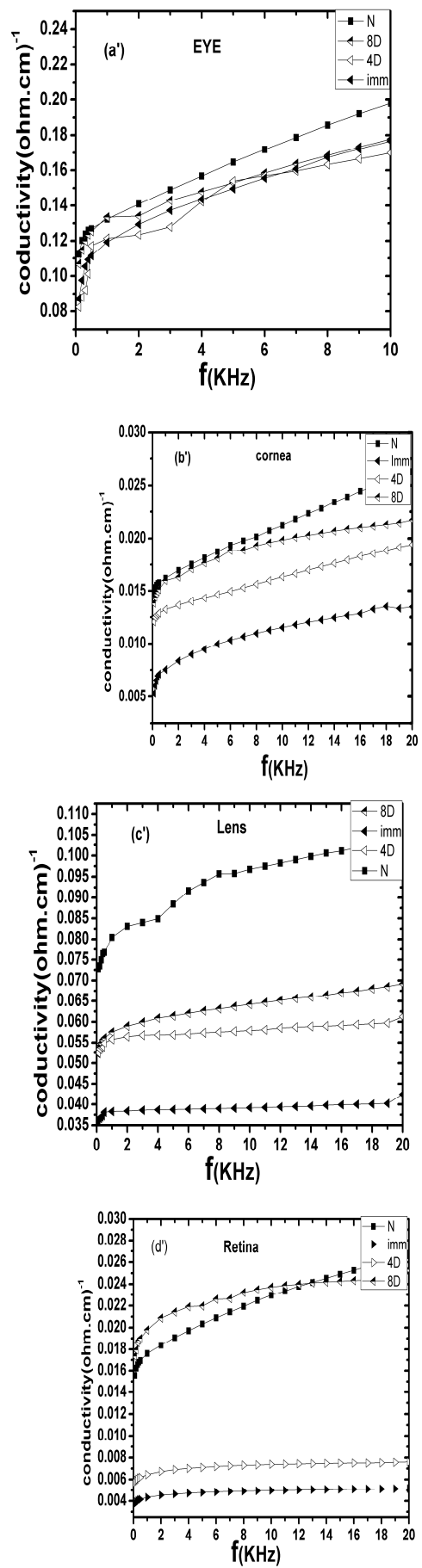

Fig 2: Frequency dependence of conductivity for whole isolated rabbit eyes and separated cornea, lens and retina 
Group(A)time $0.25 \mathrm{sec}$
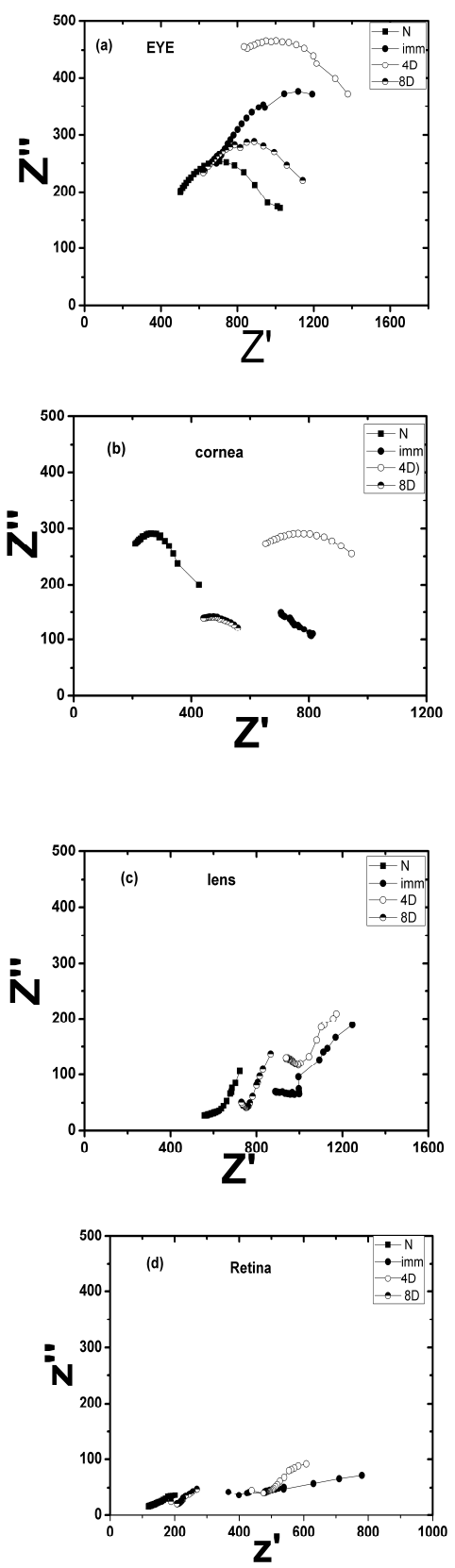

Group(A)time 0.1sec
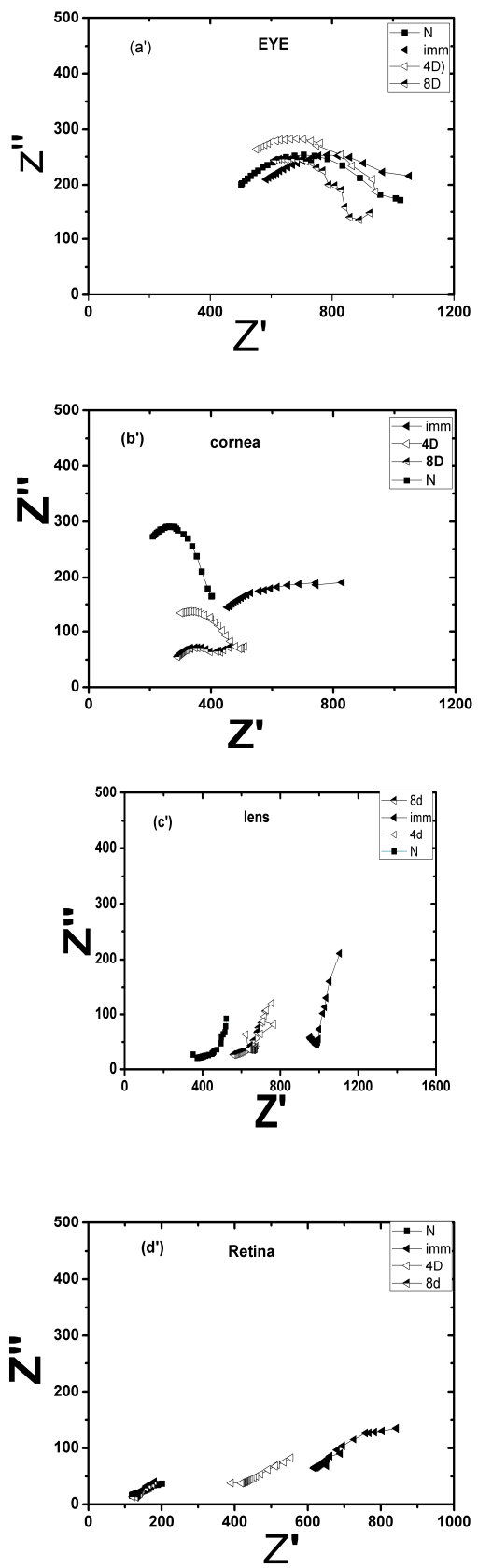

Fig. 3: Cole - Cole Plots for whole isolated rabbit eyes and separated cornea, lens and retina 
On the other hand, the obtained reduction in eye conductivity after exposure times $0.1 \& 0.25 \mathrm{sec}$ may be due to the thermal effect of Nd-YAG laser on the eye which contains different layers affected by the laser. The conductivity changes for different eye tissues may be due to that each component of eye behaving as a spectral filter absorbing specific wavelengths within the incident spectrum $[\mathbf{2 3}, \mathbf{1 6}]$. Also the low value of retinal conductivity may be due to that the incident Laser radiation was focused on the retina due to the eye adaptation to enable incident radiation between 400 and $1400 \mathrm{~nm}$ to penetrate deeply and be focused on the lightsensitive neural retina layer.

The Cole- Cole semicircles (fig. 3) demonstrating the relation between Z' \& Z" for control, immediate, 4 and 8 days after laser exposure of isolated rabbit eyes, and separated ocular tissues, in the frequency range $100 \mathrm{~Hz}-100 \mathrm{KHz}$. They show significant variations. The angle which is defined by Cole - Cole, and Z' which represented the bulk resistance of samples were found to be increased in case of immediate and $4 \& 8$ days after laser exposure. The increase in values of $Z^{\prime} \& Z^{\prime \prime}$, after exposure to $\mathrm{Nd}-\mathrm{YAG}$ laser, may be attributed to cell swelling due to the pronounced increase in the protein content which is accompanied with an increase in the collagen fibers [24-26]. Moreover, Schier and Dubourdien [27] attributed these swellings to the high $\mathrm{Ca}^{++}$flux into cells, the role which played by calcium in the hydrolytic breakdown of cell membrane phospholipids. The recorded variations perhaps may be also due to the variation in bulk resistance $Z^{\prime}$ of eye tissues after exposure, or/and to the decrease in membrane permeability to $\mathrm{K}^{+}$(or increase in permeability to $\mathrm{Na}^{+}$) and the influence of the $\mathrm{Na}^{+}$pump mechanism. These assumptions agree with Albert et al. $\mathbf{1 9 8 3}^{17}$, Sallam 2004, and Peyman et al., 2010, [28,26,16].

Moreover, on calculating the relaxation time $(\boldsymbol{\tau})$ for the isolated whole eye and ocular tissues, using the above mentioned equation 6 , before, immediately and after $4 \& 8$ days of stopping exposure, we find great variations in $\tau$ which were clearly more pronounced at $0.25 \mathrm{sec}$ exposure time (fig. 4). This behavior was observed in all eye tissues after laser exposure, while approaching normal values after 8 days of exposure.

The variations in the relaxation time $\tau$, together with the above mentioned dielectric properties may generally be due to the polarization of ions and water content of cell membrane and its permeability. Also, it could be due to the vasodilatation of the retinal blood vessels which is accompanied by an increase in capillary permeability. The repairing processes may be occurred due to some intracellular substances that are realized and gradually diffused out of the cells and this would explain the latent period of several days $[29, \mathbf{1 6}]$. 

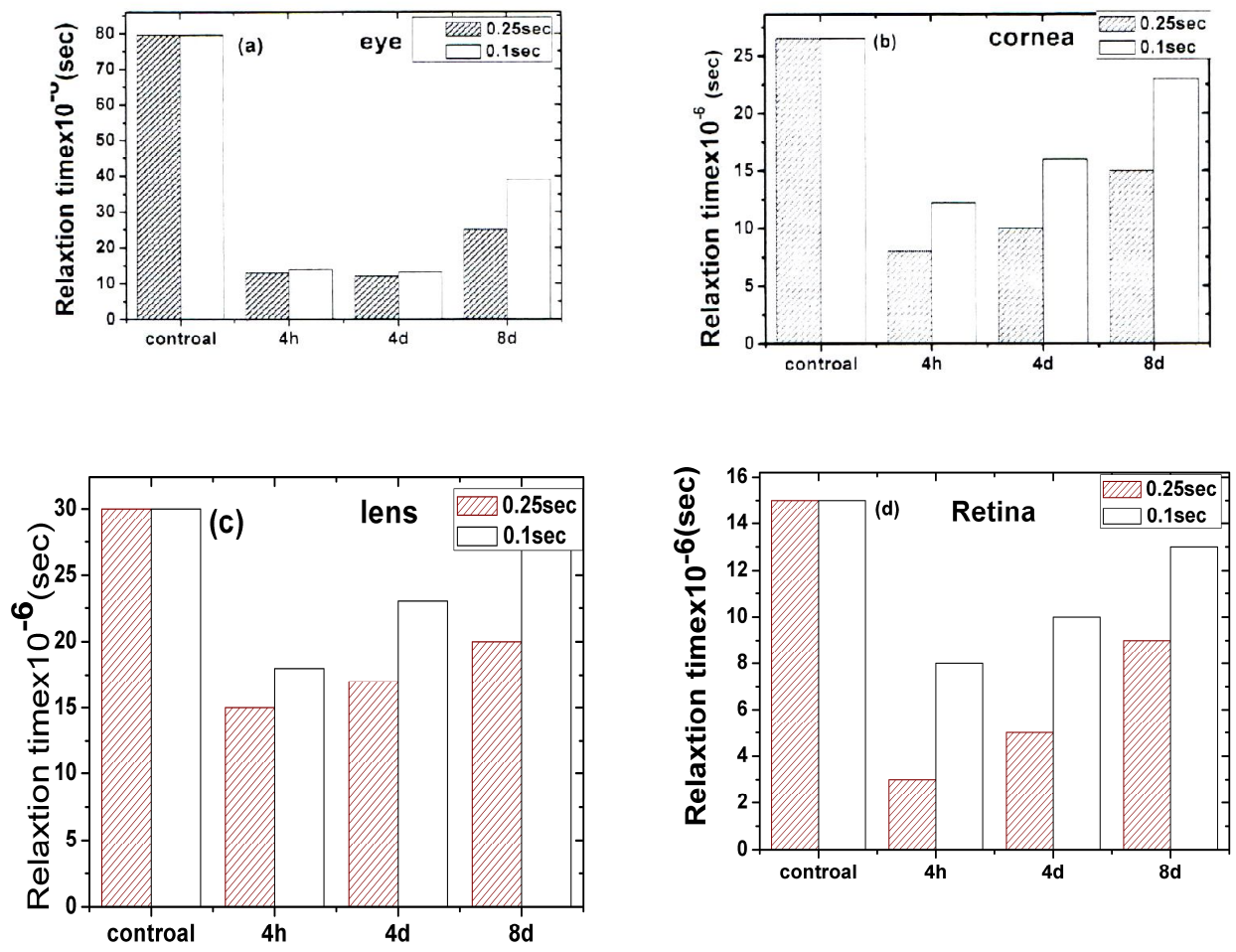

Fig.(4): Relaxation time ( $\tau$ ) of whole eye and ocular tissues for control, immediate, 4 \& 8 recovery days in case of $0.1 \& 0.25 \mathrm{sec}$ exposure time.

In this respect and depending upon the values of $\tau$, for the whole eye and ocular tissue, at all the above mentioned cases, we could calculate the molar free energy of activation $\Delta F$ for each value of $\tau$ using the relation:

$$
\Delta F=R T \ln \frac{h}{K T \tau}
$$

Where $\Delta F$ is the molar free energy of activation, and the other symbols are as their well known meanings. Table (1) represented the calculated values of activation energy of eye tissues. It's clear that the energy values are high in control and show noticeable decreases after exposure for all eye tissues; specially the activation energy of retina. These results may be due to that most of the incident radiation energy is absorbed by the retina. 


\begin{tabular}{|c|c|c|c|c|c|c|c|c|}
\hline Tissues & Eye & Cornea & Lens & Retina & Eye & Cornea & Lens & Retina \\
\hline control & $\begin{array}{l}49.6 \\
\pm 0.984 \\
\end{array}$ & $\begin{array}{l}46.8 \\
\pm 0.95 \\
\end{array}$ & $\begin{array}{l}47.16 \\
\pm 0.85 \\
\end{array}$ & $\begin{array}{l}51.15 \\
\pm 1.08 \\
\end{array}$ & $\begin{array}{l}49.6 \\
\pm 0.97 \\
\end{array}$ & $\begin{array}{l}46.8 \\
\pm 0.94 \\
\end{array}$ & $\begin{array}{l}47.16 \\
\pm 0.56 \\
\end{array}$ & $\begin{array}{l}51.15 \\
\pm 1.049 \\
\end{array}$ \\
\hline Imm & $\begin{array}{l}45.1 \\
\pm 0.822\end{array}$ & $\begin{array}{l}43.9 \\
\pm 0.93\end{array}$ & $\begin{array}{l}45.45 \\
\pm 0.98\end{array}$ & $\begin{array}{l}41.46 \\
\pm 1.03\end{array}$ & $\begin{array}{l}45.3 \\
\pm 1.07\end{array}$ & $\begin{array}{l}44.9 \\
\pm 0.58\end{array}$ & $\begin{array}{l}46.13 \\
\pm 0.69\end{array}$ & $\begin{array}{l}43.9 \\
\pm 1.079\end{array}$ \\
\hline $4 \mathrm{D}$ & $\begin{array}{l}4.9 \\
\pm .1 .04 \\
\end{array}$ & $\begin{array}{l}44.5 \\
\pm 1.079 \\
\end{array}$ & $\begin{array}{l}45.8 \\
\pm 0.58 \\
\end{array}$ & $\begin{array}{l}42 \\
\pm 0.65 \\
\end{array}$ & $\begin{array}{l}45.1 \\
\pm 0.57 \\
\end{array}$ & $\begin{array}{l}45.6 \\
\pm 0.62 \\
\end{array}$ & $\begin{array}{l}46.5 \\
\pm 0.27 \\
\end{array}$ & $\begin{array}{l}44.5 \\
\pm 1.05 \\
\end{array}$ \\
\hline $8 \mathrm{D}$ & $\begin{array}{l}46.7 \\
\pm 0.98\end{array}$ & $\begin{array}{l}45.4 \\
\pm 1.05\end{array}$ & $\begin{array}{l}46.6 \\
\pm 1.05\end{array}$ & $\begin{array}{l}44.18 \\
\pm 0.55\end{array}$ & $\begin{array}{l}47.8 \\
\pm 0.99\end{array}$ & $\begin{array}{l}46.5 \\
\pm 0.91\end{array}$ & $\begin{array}{l}47 \\
\pm 0.91\end{array}$ & $\begin{array}{l}45.1 \\
\pm 0.98\end{array}$ \\
\hline
\end{tabular}

Table (1): The mean energy values for all eye tissues for control, immediate, $4 \& 8$ recovery days $(4 \mathrm{D} \& 8 \mathrm{D})$ in case of $0.1 \& 0.25 \mathrm{sec}$ exposure time.

From the above results, it is evident that, although laser interacts with all cell membrane structures responsible for transport phenomena leading to changes in the dielectric properties, this interaction depends on the tissue type, special function of membrane and magnitude of exposure power and time of exposure which must accurately considered during choosing the laser treatment conditions for the tissue to be treated.

\section{References:}

1. Sliney .D .H, wolbarsht .M. L, (1989): future applications of lasers in surgery and medicine: a review, Journal of Royal society of medicine, 82 :(293-296).

2. Mckenzie. A.L, (1990): Physics of thermal processes in laser tissue interaction, Phys. Med. Biol , 35: (1175-1209)

3. El-Sayed. M. Elsayed, Talaat M.S and Salem E.F, (1997, 1998): Nonlinear behavior of power density and exposure time of argon laser on ocular tissue $2^{\text {nd }}$ European Biophysics Journal Congress, July, ( 13- 17), Egyptian J. Biophysics, 4(1):(55 - 68), respectively

4. Abdelkawi .S, Hassan .N, Khafagi.. M., (2012):.Effect of Green Light From Doubled Frequency Nd:YAG Laser in the Nanosecond Range on Rabbits Lens- In Vitro Study, J Lasers .Med .Sci , 3(4): (165-74).

5. Niemz .M.H, (2003): Laser tissue interaction, (Springer), 308 P., 3 th. Edition.

6. Bachmann. L, Gomes A.S.L, Zezell. D.M, (2004): Bound energy of water in hard dental tissues, 37 (6) :( 565-579).

7. 7- Steiner. R, (2011): laser tissues interactions, Springer, 2: (23-36).

8. Talaat .M.S., (1998): Retinal bio effects due to intermittent and continuous exposure to low power lasers, Egyptian J. Biophysics, 4(1): (69 - 78).

9. Ferber, (2011): Laser safety Hand Book, North western university office for research safety.

10. Furkaan .M .H , (2010): Factors affecting the required power in Nd:yag laser posterior capsulotomy after cataract surgery, Karbata J. Med, 3(1,2):(850-855).

11. Shui Y., Holekamp N. M. and Kramer B.C, (2009):Arch. Ophthalmol, 127: 475

12. Abdelkawi .S, (2012): The Rheological Properties of Vitreous Humor after Q-Switched Nd:YAG Laser Photo disruption Biophysical Reviews and Letters , 7(12): (29-39).

13. Vogel.A, Hentschel .W, Holzfuss .J and Luetrborn, (1996): Arch Ophthalmol. 93 :1259. 
14. Talaat .M.S, El-Ghandoor. H and El-Sayed E. M., (1997): Detection of laser accumulative effects on the retina using different techniques, Pure \& Appl. Opt, 6 (137 146), London

15. Peyman. A. S. H and C. Gabriel, (2010): Dielectric properties of tissues at microwave frequencies, WWW.mthr.org.UK. C/O Health Protection Agency,. Chilton, Did cot, Oxford shire OX11 ORQ.

16. Kuang .W, Nelson. S. O, (1998): Low-frequency dielectric properties of biological Tissues, a Review with Some New Insights American Society of Agricultural Engineers, 41(1):(173-184).

17. Makio.W, Toshinobu .S, and Akihiko. I, (1991): Dielectric behavior of the frog lens in the $100 \mathrm{~Hz}$ to $500 \mathrm{MHz}$ range Simulation with an allocated ellipsoidal- shells model, 59 :(139-149).

18. Dawkins .A. W. J., Gabriel .C, Sheppard .R. J and Grant E. H., (1981): Electrical properties of lens material at microwave frequencies, Phys. Med. 26:(1- 9).

19. Gabriel. C, Sheppard. R. J and E. H. Grant. , (1983.): Dielectric properties of ocular tissues at $37^{\circ} \mathrm{C}$, Phys. Med. Biol, 28:(43-49).

20. Gabriel. S, law. R.W and Gabriel. C, (1996a): The dielectric properties of Biological tissues, phys. Med .Bio, .41:(2231-2249).

21. Schwan .H.P, (1963): Physical techniques in biological research, Ed WL nastuk (new York:academic), VIB(323-407).

22. Colonel John Crompton .L, (2001): Laser in ophthalmology and the military, part (1): The effects of laser energy on human tissue, ADF Health, 2:(85-88).

23. Boettner. E .A, Wolter .J, (1962): Transmission of the ocular media, Invest Ophthalmic, ,1:(776-783).

24. Aron. R. K, Ciombor.D.M andJolly.G, (1989): Stimulation of experimental endochondrial ossification by low energy pulsing electromagnetic fields, J, Rone, Miner Res, 4(2):)223-227).

25. Rusovan.A and Kanje.J , (1992a): Magnetic fields stimulate peripheral nerve regeneration in hypo phyesctomized rats, Neuro report, 3(12):(1039-1041).

26. Sallam.S.M, (2004): The effect of static magnetic field on the dielectric properties of rat organs, Egyptian journal of biophysics, 10(2):(195-207).

27. Schier .W.T and Dubourdien D.J, (1982): Roles of phospholipids hydrolysis in the mechanism of toxic cell death by calcium and ionophore A.23-87, Biochem, Biophys Res comm., 109 :( 106-113).

28. Albert .B, Bary.D, Lewis.J, Roberts.M and Watson.J, (1983): Molecular biology of the cell.ch.6, pp.290.Garland publishing Inc., New York and London.

29. El-Sayed .M. Elsayed, Talaat. M.S and Sallam S.M, (1991): Studies on the chicken eye properties exposed to Argon laser by dielectric methods, Journal De Physique, 4 : 2007 2016). 
